\title{
Early intervention care programme for parents of neonates
}

\author{
W Lubbe, M Tech Nursing \\ Little Steps Preemie Parenting Consultancy
}

Correspondence address:

Ms Welma Lubbe

Little Steps

PO Box 68908

Highveld

0169 en e-mail

\section{Abstract: Curationis 28(3): 54-63}

Parents with neonates in the neonatal intensive care unit (NICU) experience different needs at different stages of their neonates' stay in the NICU. The needs of parents with neonates in NICU's play an important role in aspects such as the ability to cope with changing parental roles and emotions, the relationship between parent and infant and the managing of the parents' own needs. The aim of this study was to develop an intervention care programme for parents with neonates in the NICU.

This intervention care programme will empower parents to manage their own needs and the needs of their neonates while the neonate is admitted to the NICU and after discharge from the NICU / hospital. Literature is available on care programmes for neonates, but not on programmes for the parents of neonates in NICU.

The study was a multi-phased study, using qualitative methodologies to determine the needs of South African parents with neonates in level III NICU's. In phase I, the needs of parents with neonates in NICU were elicited qualitatively. The needs were identified from the data and the results led to the implementation of phase II. In phase II the question was adjusted and new data was collected. Phase III was implemented to validate the data derived from phases I and II. The data was categorised in different need categories and these categories were used to plan an intervention care programme for parents with neonates in NICU's. The programme provides information to address needs as identified by parents in the research study and as derived from the literature.

Need categories identified from the study and literature were as follows: information, communication, emotional, learning, discharge and individual needs.

This programme is available in electronic format to enable parents to obtain information according to their changing needs and to provide unlimited access to updated information.

The "Early intervention care programme for parents of neonates" will empower parents to manage their own needs and the needs of their neonates while the neonate is admitted to the NICU and after discharge from the NICU / hospital.

\section{Opsomming}

Ouers met neonate in NISE (neonatale intensiewe sorg eenheid) ervaar verskillende behoeftes op verskillende stadia van hul neonaat se verblyf in die NISE. Die behoeftes van ouers met neonate in NISE's speel ' $n$ belangrike rol in aspekte soos die vermoë om die veranderende ouerskaprolle en emosionele veranderinge te hanteer, die verhouding tussen ouer en neonaat en die hantering van die ouer se eie gevoelens. Die doel van hierdie studie was om ' $n$ intervensiesorgprogram vir die ouers van neonate in die NISE te ontwikkel.

Hierdie intervensiesorgprogram sal die ouers bemagtig om hul eie behoeftes en die van hul neonaat te hanteer, terwyl die neonaat in die NISE opgeneem is, en ook na ontslag uit die NISE / hospitaal. Literatuur is beskikbaar rakende sorgprogramme vir 
neonate, maar nie oor programme vir die ouers van neonate nie.

Hierdie studie was ' $n$ multi-fase studie, wat gebruik gemaak het van 'n kwalitatiewe navorsingsontwerp om die behoeftes van Suid-Afrikaanse ouers met neonate in vlak III NISE's te bepaal. In fase I is die behoeftes van ouers van neonate in NISE kwalitatief bepaal. Die behoeftes is geïdentifiseer vanuit die data en die resultate het gelei tot die implementering van fase II. In fase II is die vraag aangepas en nuwe data is versamel. Fase III is geïmplementeer om die data verkry uit fase I en fase II te valideer. Die data is gekategoriseer in verskillende behoefte-kategoriëe en hierdie kategoriëe is gebruik om ' $n$ ingrypingsorgprogram vir die ouers met neonate in NISE te beplan. Die program voorsien inligting om die behoeftes aan te spreek soos deur die ouers geidentifiseer in die navorsingstudie en soos afgelei uit die literatuurstudie.

Behoefte kategorieë soos geïdentifiseer uit die literatuur en die navorsingstudie, is die volgende: inligtings-, kommunikasie-, emosionele-, leer-, ontslag- en individuele behoeftes.

Die program is in elektroniese formaat beskikbaar, sodat ouers die inligting kan verkry volgens hul veranderende behoeftes en sodat hulle onbeperkte toegang tot opgedateerde inligting kan hê.

Die "Intervensiesorgprogram vir ouers met neonate" sal die ouers bemagtig om hul eie behoeftes en die van hul neonaat te hanteer, terwyl die neonaat in die NISE opgeneem is, en ook na ontslag uit die NISE/hospitaal.

\section{introduction}

Expecting a baby supposes the expectation of a normal birth and a normal infant. According to Younger, Kendell and Pickler (1997:30) the transition to motherhood is a normal developmental crisis. Therefore adapting to parenthood is an emotional experience for new parents. Although it brings change, experiencing a normal forty-week pregnancy leaves room for adapting to these emotional and role changes.

Expecting a healthy neonate and then being confronted with a neonate admitted to a NICU is not only an adaptation for the parents to a new situation; it is a nerve-racking experience. According to Shellabarger and Thompson (1993:39), parents must cope with intense and confusing emotions during the crisis of premature parenthood. These emotions stem from the following circumstances:

- $\quad$ An unexpected delivery

- $\quad$ Concern about the premature neonate

- $\quad$ Admission of the neonate to a NICU (neonatal intensive care unit)

- Transport of the neonate to a different hospital

- $\quad$ Appearance of the premature neonate

- $\quad$ Grief from the loss of an ideal pregnancy and birth experience

- The need to communicate with many unknown health care providers

Giving birth to a premature neonate is a stressor and has additional emotional and psychological effects on the parents. Dealing with the loss of the expected healthy neonate is an overwhelming psychological adjustment for the parent (Shellabarger \& Thompson, 1993:39).

The needs of parents may differ according to the illness of the baby, the length of stay in the NICU and other factors. For the purpose of this study the researcher focussed on NICU in Tshwane.

\section{Clarifying definitions}

NICU: Neonatal intensive care unit

Ievel III NICU: Specialist NICU with specialised equipment for management of very ill patients. Full time specialist nursing and medical staff available.

\section{Problem statement}

The researcher experienced that parents with neonates in NICU experience fluctuating emotions and needs. Due to a lack of knowledge regarding the care of their neonates, these parents were not empowered to manage the needs of their neonates or their own needs, while the neonate was still admitted to the NICU and after discharge from the NICU or hospital.

According to Dreyer (2000:14) parents are initially shocked by the appearance of their neonate. They are then confronted with feelings of fear, and worries about the neonate's survival or lifelong physical outcome. An overwhelming psychological adjustment for the parent is dealing with the loss of the expected healthy neonate. In addition parents have feelings of guilt in spite of reassurance. The NICU environment can also be described as a traumatic stressor. The needs and stressors mentioned are not the problem as such, but the problem is that parents of neonates in NICU are not empowered to manage their own needs or the needs of their neonate while admitted to the NICU or after discharge.

At present neonatal supportive developmental care is implemented in some neonatal units in South Africa, with positive outcomes mostly for the neonates. However there is still no intervention care programme for the parents with neonates in the NICU. Parental needs are neglected and parents are not involved in the decision making of their infant's care. Parents are not equipped and empowered to care for their neonate when it is time to take their baby home.

\section{Research aim}

The aim of this study was to develop an intervention care programme for parents with neonates in level III NICU's in private hospitals in Tshwane.

\section{Research objectives}

- $\quad$ To explore the needs of parents with neonates in NICU's regarding the care of their infant and their own personal needs

- To conceptualise the major concepts in the existing theoretical framework

- To develop an intervention care programme for parents with neonates in level III NICU's in private hospitals in Tshwane

\section{Ethical considerations}

The following ethical issues were considered by the researcher:

- Research was approved by the Faculty Research Committee and Research Ethics Committee to ensure that the risks faced by human participants in this research were minimal (Babbie \& Mouton, 2002:528)

- $\quad$ The researcher obtained informed written consent (Brink, 
PHASE I - Naïve sketches

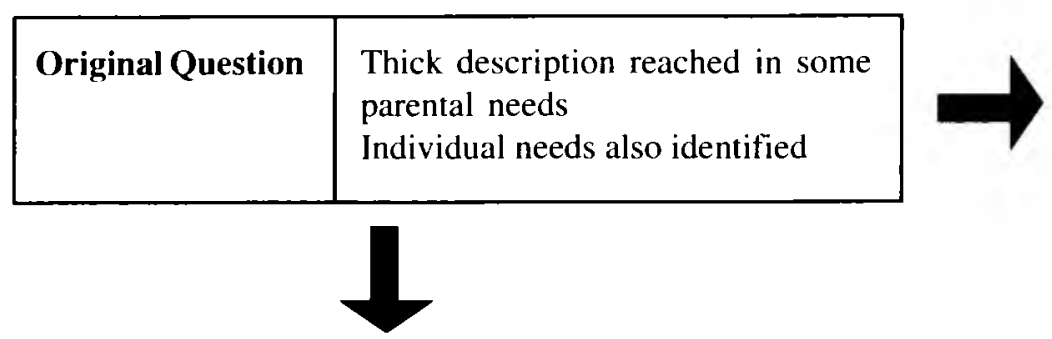

\section{Final Categories}

PHASE II - Naïve sketches

\begin{tabular}{|l|l|}
\hline Adjusted Question & $\begin{array}{l}\text { New needs identified } \\
\text { Thick description needs of phase I } \\
\text { supported }\end{array}$ \\
\hline
\end{tabular}

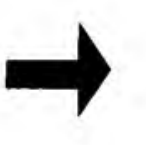

Information needs

Communication needs

Emotional needs

Learning needs

Discharge needs

Individual needs

PHASE III - Lickert-scale \begin{tabular}{l|l} 
List of statements & $\begin{array}{l}\text { Verification of needs identified during } \\
\text { phases I en II }\end{array}$
\end{tabular}

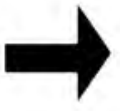

1996:42; Strydom, 2000:25-27)

from hospital and unit managers, as well as the parents with neonates admitted to the NICU A description of the study was given to the hospital and/or nursing services managers in the form of a proposal (Strydom, 2000:30)

- $\quad$ Respondents were informed that they would not be exposed to any physical or emotional harm (Strydom. 2000:25) through the consent form they filled out (Babbie and Mouton, 2002:522)

Anonymity and confidentiality was assured (Babbie \& Mouton, 2002:523-524 and Brink. 1996:45). Respondents were asked to complete a naïve sketch anonymously. Any identifying information that was accidentally included on the naive sketch was removed and all naïve sketches were numbered before handed to the co-coder

- $\quad$ Participation in the study was voluntary and respondents were informed that they might withdraw from the study whenever they wanted to (Babbie \& Mouton, 2002:521)

- $\quad$ Negative findings were reported if related to the analysis (Babbie \& Mouton, 2002:526)

- Unexpected findings were also reported (Babbie \& Mouton, 2002:526)

- $\quad$ The limits of the findings were indicated at the conclusion of the study, as well as the methodological constraints that determined the validity of such findings. Findings were fully reported and results were not misrepresented in any manner (Babbie \& Mouton, 2002:526)

- No data or observations were changed under any circumstances (Babbie \&

\section{Mouton, 2002:526)}

- $\quad$ The researcher did at all times strive to maintain objectivity and integrity in the conduct of scientific research (Babbie \& Mouton, 2002:526)

- The researcher adhered to the highest possible technical standards in the research (Babbie \& Mouton, 2002:526)

\section{Research design and method}

\section{Research design}

The study was a multi-phased study, using qualitative methodologies to determine the needs of South African parents with neonates in level III NICU's. The aim of this study was to explore and describe the needs of parents with neonates in the NICU (Babbie \& Mouton, $2002: 79-81)$. To meet this aim an exploratory and descriptive strategy with a qualitative orientation was implemented. 


\section{Research method}

The study was performed in three phases. In phase I, the needs of parents with neonates in NICU were elicited qualitatively using naïve sketches completed by parents with babies in NICU. The question asked was "What are your personal needs concerning your involvement in the basic care of your neonate in the neonatal intensive care unit? Please include any other needs you may encounter".

The needs were identified from the data using open coding and the results led to the implementation of phase Il. In phase II the question was adjusted and new data were collected. The new question was: Describe your personal needs concerning your involvement in the basic care of your baby in the NICU.

\section{Basic care may include the following:}

- Nappy changing and eye care

- $\quad$ Bathing and weighing

- Touch, positioning, cuddling and kangarooing

- $\quad$ Feeding, winding and milk expressing

- Information on alarms, baby's condition, etc.

Please include any other needs you may encounter.

Phase III was implemented to validate the data derived from phase I and phase II. The needs were written as statements and the parents could rate their needs on a Lickert-scale. The statements that reached thick description were identified as the general needs of most parents with neonates in NICU. Thick description will be discussed under sampling.

This data were categorised in different need categories and these categories were used to plan an intervention care programme for parents with neonates in NICU.

The need categories included the following:

- Information needs

- $\quad$ Communication needs

- Emotional needs

- Learning needs

- Discharge needs

- Individual needs

\section{Context}

The context for the study was contextual, described as a study in which the phenomenon of interest was studied in terms of its immediate context (Babbie \& Mouton, 2002:272; Mouton \& Marais, 1990:452).

The context for this study was both parents of a premature neonate in level III NICU's in selected private hospitals in Tshwane. The neonates must have been admitted to the NICU when the parents described their needs through naïve sketches. The researcher decided on the following inclusion criteria for respondents in the study:

- Both parents of neonates that were admitted to the NICU at the time of the study

- First or subsequent encounter with a neonate admitted to the NICU

- $\quad$ Neonates admitted to the NICU directly after birth or transferred from the nursery

- $\quad$ Neonates born in level III hospitals

- $\quad$ Parents that were available and gave permission to participate in the study

\section{Research method}

\section{Population}

For this study the target population was all the parents with a neonate(s) in NICU's in level III NICU's in private hospitals in Tshwane. The accessible population was all the parents of neonates in level III NICU's of the selected private hospitals willing to partake in the study.

\section{Sampling}

A sample will be representative of the population from which it is selected if the aggregate characteristics of the sample closely approximate those same aggregate characteristics in the population (Babbie \& Mouton, 2002:172173, 287). According to Schurink (2000:253), a sample is selected purposively and conveniently. The sample for this study was selected by including participants in the study until thick description was achieved. That is until no new information was gathered anymore. According to Babbie and Mouton (2002:172-173, 287), an indication for a study in the interpretive (qualitative) paradigm is between five (5) and 20 or 25 respondents, depending on the nature of the study and the number of times data-gathering techniques will be repeated with each respondent.

\section{Target population}

The target population was the entire group of parents that was of interest to the researcher and met the criteria the researcher was interested in studying (Brink, 1996:132). For this study the target population was all the parents with a neonate(s) in NICU's in level III NICU's in private hospitals in Tshwane. The accessible population was all the parents of neonates in level III NICU's of the selected private hospitals willing to partake in the study.

There are 13 private hospitals in Tshwane with NICU's, ranging from 4 bed NICU's to 20 bed NICU's. They are divided into level II and level III NICU's. The acuteness levels of neonates in level II NICU's do not exceed that of neonates in level III NICU's. The assumption was therefore made that level II NICU's were represented by level III NICU's and consequently the needs of parents in level II NICU's were represented by the needs of parents in level III NICU's. The hospitals that were selected as representative of the other NICU's in Tshwane were two (2) private hospitals in Tshwane. The units were the only two units with more than 10 beds per NICU. They accommodated more (a bigger number), as well as more acutely ill, neonates and were the most accessible to the researcher.

\section{Data gathering}

A pilot study was launched to test the question posed to the respondents. Naïve sketches were used since this is a self-report technique of data gathering and give the respondents the ability to express any needs without feeling intimidated (Zeelie, 1999:18).

The question asked in the naïve sketches was an open-ended question (Fouché 2000:160) requesting the respondent to describe his / her needs concerning their involvement in the basic care of their neonate in the NICU and to include any other needs they may encounter. An open-ended question approach is more likely to reveal true needs, than a direct question, which often receives an answer which the respondents think is socially desirable (Brink, 1996:160-161). With the analysis of the results from the pilot study it seemed that the respondents were not sure of the meaning of basic care and therefore the researcher, in 
TABLE 1: $\quad$ Summary of needs and categories derived from data

\begin{tabular}{|c|c|}
\hline NEEDS & CATEGORIES \\
\hline Explanation of alarms / monitors & \multirow[t]{10}{*}{ Information needs } \\
\hline Understanding of neonate's charts & \\
\hline Information repeated in writing & \\
\hline Updates on neonate's condition / progress & \\
\hline Informed on the treatment of neonate regarding - & \\
\hline Medication & \\
\hline Interventions, e.g. $x$-rays & \\
\hline Time of treatment / & \\
\hline Plan of action & \\
\hline Informed about doctor's round, ward routine / -protocol & \\
\hline Consequent advice from staff & \multirow[t]{3}{*}{ Communication needs } \\
\hline Acknowledgement and respect for personal preferences & \\
\hline Simple, clear language & \\
\hline Support from caring staff & \multirow[t]{5}{*}{ Emotional needs } \\
\hline Emotional comfort & \\
\hline Feeling of self-worth & \\
\hline Shock & \\
\hline Involvement & \\
\hline Care of neonate & \multirow[t]{12}{*}{ Learning needs } \\
\hline Talk to neonate & \\
\hline Bond with neonate & \\
\hline Take responsibility for the care of neonate & \\
\hline Changing neonate's nappy, cleaning eyes, mouth and umbilical cord & \\
\hline Winding neonate & \\
\hline Bottle or breast-feeding neonate & \\
\hline Milk expression for neonate & \\
\hline Kangarooing / cuddling of neonate & \\
\hline Bathing \& weighing neonate & \\
\hline Touching neonate & \\
\hline Position neonate & \\
\hline Discharge Support & Discharge needs \\
\hline Specific needs & Individual needs \\
\hline
\end{tabular}


collaboration with the research specialist. decided to adjust the question and add some examples of basic care for the main study. Data gathering for phase I and II were done using naïve sketches and in phase III validating of these data were done using a Lickert-scale.

\section{Data analysis}

Data was gathered through an openended question and these descriptions were categorised in order to identify concepts on the needs of the parents with neonates in NICU. The data was collected as written statements nonnumeric in nature, which therefore required qualitative analysis. The data was analysed according to Tesch's approach for data analysis of a qualitative design (Poggenpoel, 2000:343-344).

To address the issue of internal validity, the accuracy of the information and whether it matches reality, the researcher made use of an independent coder that was asked to validate the decisions made by the researcher (Creswell, 1994:158). Coding checked for reliability by having another person encode the same data and by checking for agreement (Brink, 1996:192).

\section{Trustworthiness}

The criteria for trustworthiness in this study were credibility, transferability, dependability and confirmability. Trustworthiness was illustrated according to Guba's model (Poggenpoel, 2000:348-350).

\section{(a) Credibility:}

Credibility establishes how confident the researcher is with the truth of the findings. The study will be considered credible when it presents such accurate descriptions that people, who also share that experience, would immediately recognise the description (Sandelowski, as cited by Schurink, Schurink \& Poggenpoel, 2000:331,349). This was determined through reaching a thick description in the data collection.

\section{(b) Transferability:}

This refers to the extent to which the findings can be applied in other contexts or with other respondents (Schurink et al., 2000:331,349). Within the qualitative paradigm, generalisation of results should not be done. The aim of this study was to provide an understanding of the needs of parents with neonates in
NICU's. It included a few respondents and did not aim to generalise (Babbie \& Mouton, 2002:274). The obligation for demonstrating transferability therefore rests on those who wish to apply it to the receiving context (the reader of the study).

\section{(c) Dependability:}

An inquiry must also provide its audience with evidence that if it were to be repeated with the same or similar respondents in a similar context, its findings would be similar (Schurink et al., 2000:331,350). A study cannot have credibility without dependability. If credibility can be proved it is not necessary to demonstrate dependability separately.

\section{(d) Confirmability:}

Confirmability refers to the degree to which the findings are the product of the focus of the inquiry and not of the biases of the researcher, other motivations and perspectives (Schurink et al., 2000:331). Qualitative researchers try to increase the worth of the findings by decreasing the distance between the researcher and the informants. In this study the researcher had prolonged contact with the respondents. Confirmability is the criterion of neutrality (Poggenpoel, 2000:350). This was achieved when credibility and transferability were established.

Independent coding was done to ensure trustworthiness. The independent coder for this study was a lecturer in research methodology who had experience in qualitative research. The independent coder was asked to do open coding.

In this study trustworthiness was proved through the following:

- $\quad$ Naïve sketches were obtained past thick description (sandelowski as cited by de vos, 2000:331,349).

- Data analysis protocol was developed and implemented for the naïve sketches based on Tesch's approach (poggenpoel, 2000:343-344).

- Consensus discussions were held with the independent coder.

- $\quad$ Findings, conclusion and recommendations have been supported by the data.

The data was regarded as trustworthy as it met the criteria for trustworthiness as set by Lincoln and Guba (Brink, 1996: 124125; Poggenpoel, 2000:348-350).

\section{Results}

The study was performed in three phases and the results will be discussed as such.

Phase I: The results obtained from phase I were described as needs stated by parents that reached a thick description and individual needs identified by parents.

Phase II: On analysis of the data of phase II there were still needs that did not reach thick description. This data supported both individual needs and new needs that were identified by parents with neonates in. NICU.

Phase III: Statements that were rated as agreed or definitely agreed with on the Lickert-scale, were regarded as thick descriptions. These statements were included in the data that was used to categorise and conceptualise.

A summary of the needs and categories as derived from the research data are given in table 1 .

\section{Discussion of results with justification from the literature}

Literature was explored to support the results obtained from the research study and to aid in planning an intervention care plan for parents of neonates.

\section{Information needs}

Since parents are still in a state of shock when they first enter the unit, they suggested that this information should be repeated at a later stage when they feel calmer. They also find written requests or information easier to remember, for example provision of nappies. When parents are anxious, they may not be able to understand or retain information. It may be nessesarry to repeat information several times.

In addition, creative presentation of material through visual presentation. videotapes and computers may be helpful (Reichman, Miller, Gordon \& HendricksMunoz, 2000:290). Sweeney (1997:65) supported the importance of access to written information. The need to repeat information and interpret explanations. because of the inability of parents with 
neonates to remember information the first time it is given, is supported by Reichman, Miller, Gordon and HendricksMunoz, (2000:290), McKim, as cited by Yssel (1998:18), and Shellabarger and Thompson (1993:42).

\section{Emotional needs}

According to Ruben as cited by Younger, Kendell and Pickler, (1997:30), giving birth during the second trimester of pregnancy results in role confusion for the mother. Mothers that deliver prematurely and give birth to premature neonates have been known to also experience increased stress and depression during the early postpartum period. According to Haut, Peddicord and O'Brien, (1994:19) a premature birth precipitates a crisis for parents, forcing them to redefine and adapt their parenting roles. Parents dealing with the loss of an expected healthy neonate need to make overwhelming psychological adjustments. Ward and Hayes (2001:282,284) and Trowell and Bower (1995:54-57), stated that parents of neonates in the NICU often describe feelings of shock, self-blame, anticipation, despair, pain, helplessness, anger, raised levels of depression and / or anxiety and uncertainty concerning the neonate's health outcomes, especially during the first week of hospitalisation.

\section{Communication needs}

Parent-neonate separation is inevitable when the neonate requires neonatal intensive care. Parents are denied to see, touch or hold their neonates before they are taken to the NICU. If they are allowed to see their neonate, it might be for only a few seconds, which do not allow for parent-neonate interaction. This separation is extremely painful for the parents, and it greatly increases their anxiety and fear. Grief and loss are very real to these parents. Parents should also be reassured that communication channels are open to keep them well informed about the current condition of their neonate.

During the initial NICU visit communication needs are particularly great, because parents must learn a new language, establish trust in new relationships, and accept their role in this setting. Parents display a variety of verbal and non-verbal signs to indicate that they are struggling to gain a sense of security in the NICU.
During the hospitalisation of the neonate three (3) specific communication issues are of great importance to parents, namely information sharing, decisionmaking and encouraging contact with their neonate - especially touch. According to Shellabarger and Thompson (1993:42) and Raines (1998:43), parents need to be included in decision-making about issues such as scheduling baths or feeding, clothing for the neonate, and choice of skin care products as an important means of support. Inclusion in decision-making helps parents to understand what is happening to their neonates and gives them opportunities to ask questions, express feelings and concerns, and establish trust relationships with staff. It also helps them internalise a parental sense of responsibility. Parents felt more helpless and have more difficulty adjusting if they are not involved in decisions. Pinch and Spielman (1989:1018), Raines (1996: 10; 1998:42-43) and Sweeney (1997:65) stated that the involvement of parents in decisionmaking is not optional, but should be a standard practice.

Shellabarger and Thompson (1993:40-44) and Maroney (1994:132) also stated that support is perceived as helpful when it gives the parents back some control via providing information. Encourage parents to spend as much time as possible with their neonate and participate in the neonate's bathing, feeding and changing as soon as it is medically safe.

Parents should be encouraged from the beginning, to touch, stroke, and speak to their neonate as far as possible. When the neonate is ready, they can change, feed and continue to comfort and soothe their neonate (Reichman et al., 2000:291). The early introduction of positive touch lays the foundation for continued positive interaction with the neonate.

\section{Learning needs}

Learning needs include information or skills that parents with neonates in NICU's need to acquire in order to be able to care for their neonates. Specific learning needs stated in the literature includes: Interventions (White-Traut, 2003) and (Cusson \& Lee, 1994:66), bonding (Haut, Peddicord \& O'Brien, 1994: 19-25), interaction with the neonate ( Shellaberger \& Thompson, 1993:43), basic care of the neonate (World Health
Organisation, 1996; Yssel, 1998:21) and feeding of the neonate (Wereszczak, Miles \& Holditch-Davis, 1997).

\section{Discharge needs}

When it is time for the discharge of the neonate from the NICU, the goal of all the communication that has occurred throughout the entire NICU experience, is reached. The anticipation and tentative joy can be accompanied by feelings of fear, anxiety, low self-esteem, failure, and inability to cope (Drake, 1995:49, Roets, 1995:5, Shellabarger \& Thompson, 1993:43; Van der Heyde, 1993:47). The negative emotional states appear to be heightened just prior to the neonate's hospital discharge (Doering, Moser \& Dracup, 2000:15).

\section{The programme}

Intervention care programmes has been implemented for different reasons. Cusson and Lee (1994:61) stated that with adequate support and early contact. the mother may be assisted to focus on the positive aspects of her neonate. Mothers, who have difficulty interacting with their neonates, may become more communicative with their neonate if assisted with early interventions.

\section{Existing programmes}

Existing care programmes for the parents of neonates that are relevant to this study include the following:

- Budin (Cusson \& Lee, 1994:6061)

- $\quad$ Parent information binder (Costello, Bracht, Van Camp \& Carman, 1996:44-45)

- Parental interventions and the development of the preterm infant (Cusson \& Lee, 1994:6068)

- Development interventions for preterm and high-risk infants (Staff of the Children's Hospital, Denver, Colorado)

According to Parrish, (2003) Programme Specialist for Family Partnerships from the Institute for Family-Centred Care, parent intervention care programmes might include learning how to physically and medically care for a fragile infant, preparing for discharge to home, linking to community resources, learning to identify behaviours and developmental patterns, learning to communicate with medical staff and developmental 
specialists, or working with other parents in support groups.

\section{Early Intervention Care \\ Programme}

From the data derived from the research and literature study an "Early intervention care programme for parents of neonates" was compiled. The programme provides information to address needs as identified by parents and as derived from the literature study.

This programme is based on the programmes of Budin (Cusson \& Lee, 1994:60-61), Costello (Costello, Bracht. Van Camp \& Carman, 1996:44-45) and Cusson (Cusson \& Lee, 1994:60-68), combined with the Developmental interventions for preterm and high-risk infants programme by the staff of the Children's Hospital, Denver, Colorado. The contents of the programme have been determined by data gathered from this study and from national and international literature. This therefore addressed the research question: What will an intervention care programme for parents of neonates consist of? All the information included in the programme has not been developed by the researcher, but links to updated websites have been used to give parents the opportunity to obtain updated information and be linked with other reliable resources.

This programme has been developed to answer the needs of parents with neonates admitted to the NICU; therefore the aim of the study has been reached. The programme aimed to lead to the empowerment of parents to manage their own needs and the needs of their neonates. The contribution of this programme is that the programme is offered via multimedia and the advantage of such a medium is that it is selfregulated learning. Parents are enabled to obtain information according to their changing needs and provided unlimited access to updated and reliable information. They can refer back to any part of information whenever they want. without feeling that they are bothering the staff. The result of this is less nursing hours spent on repeating information to parents with neonates in NICU, more frequent updating of information and building parent confidence. Parents can be linked to websites specific to the condition of their neonate via the Internet and on-line support groups can also be created. The "Intervention care programme for parents of neonates" is outlined as follow:

Page 1 of the "Intervention care programme for parents of neonates" contains general information specific to the working of the programme and discusses the objectives of the programme. Page 2 includes general information regarding NICU's. Activities are included for the parents to complete in order to gather information specific to the NICU their baby is admitted to. Activities on using of the Internet are also included to address parental support needs. These activities include the "Chat box" where parents can share information with other parents and the "E-mail" function that enables them to contact professionals with any questions they may have. Page 3 is the page with important educational information. Again not all information could be given by text, but could be gathered through activities or web links. Page 4 discusses and demonstrates feeding options for the premature neonate. Finally, page 5 contains information regarding the discharge of a premature neonate from the NICU to home. This page will only be of use for those parents whose neonates are about to be discharged. Their needs should already have been addressed if the programme were implemented from the day of admission, therefore this page concentrates on an activity containing a checklist of skills the parents should have mastered at the time they are taking their neonate home. It also contains web links for further support and information on neonatal development and milestones.

Since this is an interactive computer based programme, parents will receive the $\mathrm{CD}$ together with an information file. This is an empty ring binder that can be filled with information as the parents collect it. This ring binder can be collected from the researcher.

\section{Recommendations from the research study}

Several recommendations arose form the research study and were supported by the literature. It focused on a change in the approach and education of parents with neonates admitted to the NICU. Recommendations suggested by parents of neonates and literature, regarding the approach to and education of parents, are discussed following.

Recommendations suggested by literature, regarding the approach to and education of parents:

- Identification of each neonate's level of behavioural organisation and recognition of their stress and stability signals by their parents.

- $\quad$ Effective antenatal preparation of parents for admission of their neonate to the NICU.

- The provision of adequate parent facilities such as quiet rooms, comfortable areas to express breast milk, crèches for other siblings and "rooming-in" areas to allow parents to stay with their neonate should they desire it

- $\quad$ Before NICU nurses can meet the needs of parents of hospitalised neonates. they must become cognisant of these needs as identified by parents of neonates in the NICU

- Healthcare professionals should facilitate attachment. The role of healthcare professionals should be based on the premise of promoting early physical contact with the neonate as well as opportunities to see and be close to the neonate

- Answer parents' questions honestly

- Consistency in caregivers must be provided as well as a proper care plan, developed with parental input, that is followed by all caregivers

- Diagrams should be used in the explanation of the neonate's condition

Recommendations suggested by the research study, regarding the approach to and education of parents:

- Involve parents in the basic care of their newborns as soon as possible

- Continuously inform them of the neonate's treatment plan, procedures and progress

- $\quad$ Explain monitors and alarms in the unit

- $\quad$ Actively listen to their fears and expectations, and be supportive

- Demonstrate a genuine concern for the whole family 
Assist parents in understanding neonatal responses to hospitalisation

- Handle the neonate gently

- $\quad$ Provide comfort measures to the neonate

- $\quad$ Provide guidance regarding the feeding of their neonate.

- $\quad$ Provide an estimated time frame

- $\quad$ Manikins can be made available for parents to practise on while their neonate is ventilated, if they are too afraid to touch their neonate or if they need to practise skills such as cardio pulmonary resuscitation (CPR)

- $\quad$ Parents must be given the option to stay present in the case of an emergency or resuscitation

- $\quad$ Lay terms must be used to explain conditions to parents and information should be repeated regularly or be available on a repetitive basis

- Parents can be taught how to provide positive touch for their neonates

Suggestions made by the researcher included that equipment such as computers with printers and Internet should be installed in NICU's to make the programme accessible to everyone.

Suggestions for further research included:

- Bibliographical data should also be included in data gathering as including this data may result in more specific information regarding the following:

$>\quad$ First or subsequent encounter with the NICU.

$>\quad$ Differences in needs between mothers and fathers.

Changes in needs depending on the age and weight of the neonate.

$>\quad$ The length of stay of the neonate in the NICU.

$>\quad$ The ethnicity of the respondents.

- Testing and implementation of the programme in NICU's in South Africa.

\section{Concluding statement}

Parents with neonates admitted to NICU experience fluctuating emotions and needs. This statement is supported by literature. The neonate's clinical instability and dependency on modern high technology to maintain life have created the belief that nurses are trained the best to care for the premature neonate. As a result, the emotional needs of the parents are seen as secondary to the neonate's condition. Parents are not involved in the decision-making of their neonate's care, nor are they equipped or empowered to care for their neonate when it is time to take him/her home. Due to a lack of knowledge regarding the care of the neonates, the parents are not empowered to manage the needs of their neonates or their own needs, while the neonate is still admitted to the NICU and after discharge from the NICU or hospital.

The aim of this study was to develop an intervention care programme for parents with neonates in level III NICU's in private hospitals in Tshwane. This aim was reached.

The research study addressed the needs of parents with neonates in the NICU and the research outputs of the study answered to the specific objectives formulated for the study. The outcomes of the study corresponded with the aims and objectives of the study, and the statement can therefore be made that the aim of the study was achieved.

It is unfortunate that any neonate has to be admitted to the NICU, since it causes emotional turmoil in the pregnancy and birth situation that should have been a wonderful experience, but if parents are empowered to fulfil their parental role and they can feel involved in the care of their neonate, even the NICU experience may be a great experience. It is important to give parents some knowledge since, "...knowledge and power are closely related and mutually dependent" (Babbie \& Mouton, 2002:40).

Parents are just as important in the NICU as the neonate. Health care professionals should therefore never forget that it is the parents' precious little baby that is admitted to the NICU and they have the right to be there, care for and love him / her.

Never forget, we are experts too.

We are parents, experts in love.
Please help us do for our child What you would do for yours.

Peter Cumming

(Parent of a neonate)

\section{Bibliography}

BABBIE, E \& MOUTON, J 2002: The practice of social research. Cape Town: Oxford University Press.

BRINK, HI 1996: Fundamentals of research methodology for health care professionals. Cape Town: Creda Press.

COSTELLO, A;BRACHT, M;VAN CAMP, K \& CARMAN, L 1996: Parent information binder: individualizing education for parents of preterm infants. Neonatal Network. 15(5), August: 43-46.

CRESWELL, JW 1994: Research design: qualitative and quantitative approaches. New Delphi: Sage.

CUSSON, RN \& LEE, AL 1994: Parental interventions and development of the preterm infant. JOGNN. 23(1), January: 60-68.

DE VOS, AS (ed.) 2000: Research at grass roots: a primer for the caring professions. $2^{\text {nd }}$ ed. Pretoria: Van Schaik.

DOERING, LV; MOSER, DK \& DRACUP, K 2000: Correlates of anxiety, hostility, depression, and psychosocial adjustment in parents of NICU infants. Neonatal Network, 19(5), August: 15-23.

DRAKE, E 1995: Discharge teaching needs of parents in the NICU. Neonatal Network. 14(1), February: 49-53.

DREYER, A 2000: Developmentally supportive care in the NICU with guidelines to the neonatal therapist. Photostat copy.

FOUCHÉ, CB 2000: Data collection methods. In: De Vos, A.S. (ed.). (2000). Research at grass roots: a primer for the caring professions. $2^{\text {nd }}$ ed. Pretoria: Van Schaik.

HAUT,C; PEDDICORD, K \& O'BRIEN, E 1994: Supporting parental bonding in the NICU: a care plan for nurses. Neonatal Network. 13(8), December: 1925.

MARONEY, D 1994: Helping parents 
survive the emotional "roller coaster ride" in the newborn intensive care unit. Journal of Perinatology. 14(2): 131-133.

MOUTON, J \& MARAIS, HC 1990: "Basiese begrippe" metodologie van die geesteswetenskappe. Pretoria: TGNUitgewers.

PARRISH, RN 2003, July 11: Subject: Research on intervention care programmes. [Online]. Personal E-mail from R.N. Parrish, Program Specialist for Family Partnerships, Institute for FamilyCentred Care<rparrish@iffcc.org>.

PINCH, WJ \& SPIELMAN, ML 1989: Ethical decision making for high-risk infants. Nursing Clinics of North America, 24(4), December: 1017-1023.

POGGENPOEL, M 2000: Data analysis in qualitative research. In: De Vos, A.S. (ed.). (2000). Research at grass roots: a primer for the caring profession. Pretoria: Van Schaik.

RAINES, DA 1998: Values of mothers of low birth weight infants in the NICU. Neonatal Network. 17(4), June: 41-46.

REICHMAN, SRF; MILLER, AC; GORDON, RM \& HENDRICKSMUNOZ, KD 2000: Stress appraisal and coping in mothers of NICU infants. Children's Health Care. 29(4): 279-293.

ROETS, L 1995: Verpleegkundige beraming van die behoeftes van moeders met voortydse babas. Curationis. 18(3): 415 .

SCHURINK, EM 2000: Designing qualitative research. In: De Vos, A.S. (ed.). (2000). Research at grass roots: a primer for the caring professions. $2^{\text {nd }}$ impression. Pretoria: Van Schaik.

SCHURINK, WJ; SCHURINK, EM \& POGGENPOEL, M 2000: Focus group interviewing and audio-visual methodology in qualitative research. In: De Vos, A.S. (ed.). (2000). Research at grass roots: a primer for the caring professions. $2^{\text {nd }}$ impression. Pretoria: Van Schaik.

SHELLABARGER,SG \& THOMPSON, TL 1993: The critical times: meeting parental communication needs throughout the NICU experience. Neonatal Network. 12(2), March: 39-45.
STAFF OF THE CHILDREN'S

HOSPITAL. 1995: Developmental interventions for preterm and high-risk infants. Self-study modules for professionals. Unpublished.

STRYDOM, H 2000: Ethical aspects of research in the caring professions. In. De Vos, A.S. (ed). (2000). Research at grass roots: a primer for the caring profession. Pretoria: Van Schaik.

SWEENEY, MM 1997: The value of a family-centered approach in the NICU and PICU: one family's perspective. Pediatric Nursing. 23(1), Jan-Feb: 43(3).

TROWELL, J \& BOWER, M 1995: The emotional needs of young children and their families. London: Clays.

VAN DER HEYDE, ME 1993: Die belewenis van ouers met 'n siek premature baba. Curationis, 16(3): 45-49.

WARD, K \& HAYES, JS 2001: Perceived needs of parents of critically ill infants in a neonatal intensive care unit (NICU). Pediatric Nursing. 27(3), May/ June: 281 .

WHITE-TRAUT, $R$ 2003: Low tech interventions: high impact results for mothers and their infants. Presentation at midwifery symposium. 1-27.

WERESZCZAK, J; MILES, MS \& HOLDITCH-DAVIS, D 1997: Matemal recall of the neonatal intensive care unit. Neonatal Network. 16(4), June: 33-40.

YOUNGER, JB; KENDELL, MJ \& PICKLER, RH 1997: Mastery of stress in mothers of preterm infants. Journal of the Society of Pediatric Nurses. (2)1, January-March: 29-34.

YSSEL, K 1998: Die leerbehoeftes van ouers met premature babas. M.Cur. verhandeling, Randse Afrikaanse Universiteit.

ZEELIE, SCD 1999: Wilmed medical research projects facilitated protocol development. Unpublished. 